\title{
Factor Analysis of E-Marketing as a Marketing Strategy in Creating Visits in Benan Island Marine Tourism
}

\author{
Iranita $^{1}$, Firmansyah Kusasi ${ }^{2}$, Lia Suprihartini ${ }^{3}$ \\ \{iranita@umrah.ac.id ${ }^{1}$, fkusasi@gmail.com², liasuprihartini@umrah.ac.id ${ }^{3}$ \} \\ ${ }^{1,2,3}$ Raja Ali Haji Maritime University
}

\begin{abstract}
Tourists interested in visiting a tourist destination enjoy the tourism potential of the region's natural beauty and regional arts and culture. Benan Island Marine Tourism is one of the marine tourism destinations with the advantages of exotic underwater scenery and has the potential for natural, cultural, religious, and culinary. The practice of e-marketing in the tourism sector makes it easier for tourists to find tourist destinations quickly and can reach consumers directly. The purpose of this research is to analyze the factors of e-marketing in creating interest in tourist visits. The sampling technique combined purposive and accidental sampling. The method used is factor analysis. The rotation results show that the variables are reduced to 4 factors: Website, search engine optimization, PPC advertising, affiliate marketing, and strategic partnership. The findings show that the Website was the most influencing factor in creating tourist interest in visiting the marine tourism of Benan Island.
\end{abstract}

Keywords: E-Marketing, Visit Interest Traveler

\section{Introduction}

\subsection{Research Background}

Indonesia consists of thousands of islands, hundreds of races, and tribes supported by natural wealth and natural beauty. The tourism sector in Indonesia is considered the most significant foreign exchange contributor. Tourism is a sector that can support economic, sociocultural development and advance the image of the Indonesian nation in the eyes of other countries in the world. The natural resources have the potential to be utilized and developed to become tourist attractions.

The main reason tourists are interested in visiting Indonesia is its natural beauty and various extraordinary cultural arts. It isn't perfect if foreign tourists only know a few areas even though they are imposing.

The tourism sector needs to develop further and attract domestic and foreign tourists to visit Indonesia. Every region in the world is competing to develop its tourism. Besides improving the economy, tourism can also become a brand that describes the characteristics of an area. It can also provide significant progress in each tourist destination's social, political, and cultural aspects. 

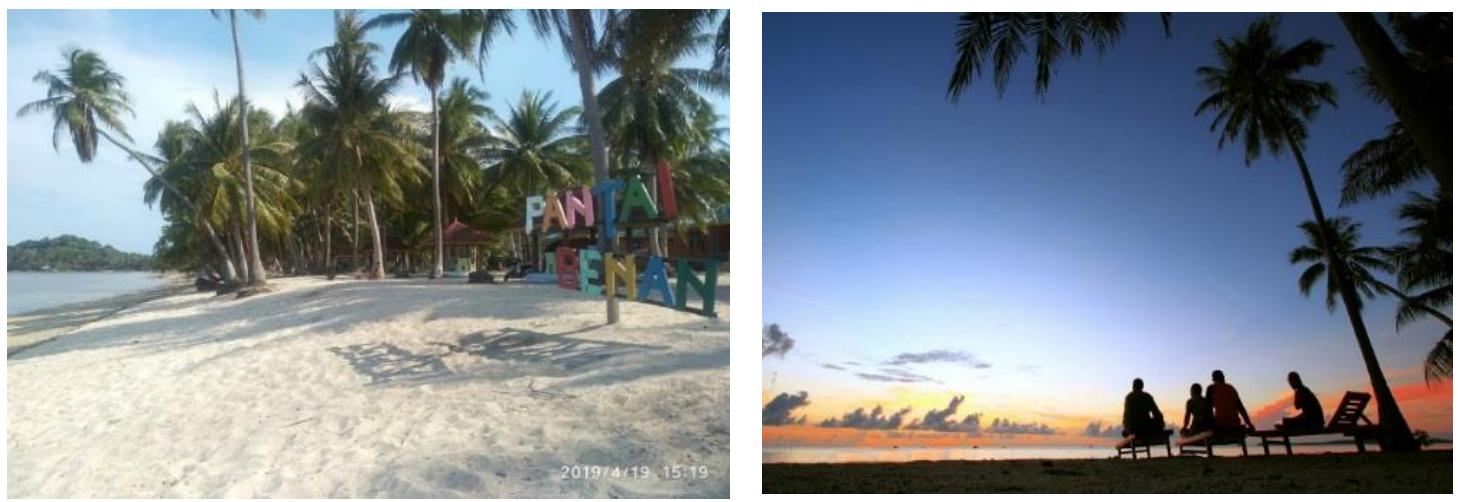

Fig.1 Picture of Marine Tourism Potential of Benan Island

Marine Tourism Destination, Benan Island, is one of the tourist destinations in Lingga Regency, Katang Bidare District Riau Islands Province, which has the advantage of exotic natural scenery, cultural, religious, and culinary tourism potential. In addition, Benan Island Marine Tourism has the potential for marine tourism with the charm of an enchanting underwater wealth of coral reefs, tropical fish, and various other marine species that will provide an experience that is difficult to forget. However, the natural potential of Benan Island Marine Tourism is not widely known to many people because so far, it is managed independently by the local community, and its promotion is only by word of mouth

Regions must map changes in the environment, target markets, regional competitors, and changes within the area to help build city branding, such as making a marketing plan for a tourist destination. The development of overgrowing technology and information can provide convenience to the public in quickly accessing information. The ability to access information is by a cellular phone or Smartphone as a tool because the Smartphone offers various devices such as the internet, Google, Instagram, Facebook, Email, and others.

Hootsuite released data and trends in the internet and social media usage in 2020. In Indonesia, out of 272.10 million, 175.40 million people are using mobile devices and the internet. Approximately 160 million are active social media users (e.g., Facebook and Instagram).

From this data, we find that there is potential for e-marketing because using modern marketing techniques such as online marketing, viral marketing, search engine marketing, and email marketing will be more successful in meeting the competition (Gautam et al. 2014).

Prospective tourists can easily find information about tourist destinations on the internet before making online purchasing decisions. However, sometimes the level of digitalization of the local community still has difficulty accessing technology. ${ }^{1}$

In the tourism sector, e-marketing practices can make it easier for tourists to quickly find destinations in all corners of the world. Hence, marketers need to continue to increase

${ }^{1}$ Organisation for Economic Co-operation and Development (OECD) ,2020. programme for international student assessment (PISA).

[https://www.oecd.org/pisa/Combined_Executive_Summaries_PISA_2018.pdf. PISA-2015-

Indonesia.pdf.; accessed on 02 August 2021] 
their web and social media presence to promote tourist destinations. The tourism business must communicate products and services intensively by marketing products using EMarketing and utilizing social media to reach consumers directly. It is in line with Safira et al.'s (2019) finding that E-Marketing can increase tourists' interest in halal tourism in Yogyakarta. The research intends to ascertain whether online tourism marketing practices are efficient and effective. For this purpose, marketers need to develop assessments that can help managers compare the best marketing practices with other managers.

Additionally, e-marketing (e.g., Facebook marketing, email marketing, weblog marketing, and Instagram marketing), either simultaneously or partially, has a positive and significant effect on tourist interest in visiting Saronde Island (Hasan \& Hatibie 2014). Technological developments, especially during the COVID-19 pandemic, have encouraged almost all activities in various sectors to utilize the online-based internet (Iranita 2020).

From the above discussion, we need to examine the Implementation of e-marketing factors as a marketing strategy in creating interest in tourism to Benan Island Marine Tourism Island. Therefore, the title of this paper is 'Factor Analysis of E-Marketing as a Marketing Strategy in Creating Visitor Interest in Benan Island Marine Tourism.'

\subsection{Research Purposes}

Based on the problem formulation described previously, this study aims to analyze the implications of e-marketing factors as a marketing strategy in creating tourist visits to marine tourism in Benan Island.

\subsection{Literature Review}

At this time, marketing has developed along with high technology such as the internet. The use of the internet and internet equipment facilities to carry out marketing activities is known as e-marketing. E-marketing is the marketing side of e-commerce, and it consists of company efforts to communicate about, promote and sell products and services via the internet. Reedy et al.(2000) noted that e-marketing utilizes network technology, among others: to coordinate market share research, to assist in product development, to develop strategies and tactics in attracting customers, to provide online distribution, to maintain customer records, to create customer satisfaction, and to collect customer feedback. Emarketing may advance marketing programs that support the company's objectives of implementing e-commerce

Rangkuti (2013) suggested that e-marketing affects traditional marketing in two ways. Firstly, e-marketing increases efficiency in conventional marketing functions. Secondly, the technology of e-marketing is changing many marketing strategies. The result of changes in this new business model can add customer value and increase company profits

E-Marketing is one of the marketing media currently in great demand by consumers to support various activities. They are gradually starting to leave the conventional/traditional marketing model towards modern marketing, namely digital marketing. With digital marketing, communication and transactions can be done anytime, in real-time, and globally. The increasing number of chat-based social media users and the more open opportunities for marketers to develop their smartphone market. The dimension of e-marketing in terms of promotion is part of the marketing mix (4P) according to (Ryan 2016; p.35) as follow: 
1) Website: A website is a link to the digital world as a whole and perhaps the essential part of an overall digital marketing strategy, where online activities are for potential consumers directly.

2) Search Engine Optimization (SEO): One of the essential parts of the Website is SEO (search engine optimization), or the process of setting the Website's content so that internet users and other search engines easily find it.

3) Paid search click-based advertising: PPC (pay per click) advertising allows marketers to purchase internet search results pages based on selected keywords and sentences.

4) Affiliate marketing and strategic partnership: The activity of partnering with other organizations/companies and websites to achieve mutual benefits from a partnership to promote a product or service.

5) Online public relations (Online PR): Using online communication channels such as press releases, article syndication (RSS), and blogs to create a positive perception of the brand and to position the organization/company as an authority in a particular field

6) Social networks: A marketing opportunity, but currently, no one has offered an advertising system with a specific focus on a tiny group of people based on profile information obtained from social networking sites.

7) Email marketing: Electronic mail (email) is still an essential tool for digital marketing activities to maintain relationships between existing consumers and prospective customers who are willing to receive information via email.

8) Customer Relationship Management: Keeping existing customers and building mutually beneficial partnerships is one of the crucial elements of digital marketing activities.

\subsection{Tourist Visiting Interest}

Interest is an impulse whereby a robust internal stimulus motivates action and feelings towards a product or service. Interest is a sense of liking and interest in a thing or activity without anyone asking. Interest is the acceptance of a relationship between oneself and something outside oneself - the stronger or closer the relationship, the greater the interest (Albarq 2013).

In addition, interest is related to tourists' plans to buy, use or enjoy certain products and the number of product units needed in a certain period, reflecting the intent to purchase a certain number of products or brands. Interest is an essential component of tourist behavior in creating attitudes. A person's tendency to act before a buying execution comes after a motivation. It is motivation as an internal force that drives individuals to take action (Hasan 2013). Furthermore, the theory of tourist visiting interest is analogous to buying interest. Research by (Aprilia et al. 2015) equates the tourist visiting interest as the consumer buying interest.

\subsection{Indicators on Interest of Tourist Visit}

The interest of tourists visiting a destination is the same as consumer buying interest. It is because both can be measured using the same indicators. Whereas, buying interest is measured by the following indicators (Kotler et al. 2014):

1. Transactional interest is a tendency to buy a product.

2. Referential interest is the tendency to refer products to others.

3. Preferential interest is the interest of someone who has a primary preference for a product and is substitutable if something happens to their preferred outcome. 
4. Explorative interest is someone's interest in looking for information about the product they are interested in and supporting information about it.

\subsection{Research Framework}

Fig. 2 below shows the framework for this research that depicts the lists of factors in emarketing that influence the interest of tourist visits.

\begin{tabular}{|c|c|}
\hline $\begin{array}{ll}\text { E-Marketing } \\
\text { a. } & \text { Website } \\
\text { b. } & \text { SEO } \\
\text { c. } & \text { PPC } \\
\text { d. } & \text { Marketing Affiliation } \\
\text { e. } & \text { Online PR } \\
\text { f. } & \text { Social Network } \\
\text { g. } & \text { Email Marketing } \\
\text { h. } & \text { CRM }\end{array}$ & \begin{tabular}{cl}
\multicolumn{2}{c}{ Interest of Tourist Visits } \\
a. & Transactional \\
b. & Refferential \\
c. & Preferential \\
d. & Explorative
\end{tabular} \\
\hline
\end{tabular}

Fig.2 Research Framework

\section{Research Methods}

\subsection{Research Design}

Data collection in this study used a survey method. The primary data collection technique used a non-probability sampling design since the population is indefinite. The sampling technique used is purposive sampling with the criteria that individuals have visited the Benan Island Marine Tourism destinations. The research location was in Benan Island. The sampling technique is accidental random sampling due to the limited workforce, time, and cost. Other members of the population are considered homogeneous. In this case, the number of respondents was 100 respondents based on Resco's theory (Sujarweni 2015).

\subsection{Analysis Method}

In this study, we utilize the Likert scale of 5-level. The Implementation of performance consists of very good, good, good enough, not good, and very not good. The five assessments are weighted to obtain answers to the research objectives by using factor analysis. This research uses the Factor analysis method to find the significant factors in the e-marketing indicators; it is a data reduction method to find new variables called factors that are fewer in number than the original number and are not correlated. The new variable contains as much information as possible, as contained in the original variable (Kuncoro 2009).

According to Sarwono \& Prihartono (2012) the factor analysis model expresses the following formula: 
$\mathrm{Xi}=\mathrm{Aij}+\mathrm{Ai} 2 \mathrm{~F} 2+\mathrm{Ai} 3 \mathrm{~F} 3 \ldots .$. AimFm + ViUi with description :

$\mathrm{Xi}=$ the $\mathrm{i}$-th standard variable

Aij $=$ Standard Multiple Regression Coefficient of the $\mathrm{i}$-th variable on the common factor $\mathrm{j}$

$\mathrm{F}=$ Common Factor

$\mathrm{Vi}=$ Standard multiple regression coefficients of $\mathrm{i}$-variable on i-unique factor

$\mathrm{Ui}=$ Variable unique factor-i

$\mathrm{m}=$ Number of common factors Unique factors correlate with each other and with common factors

Common factors expresses as a linear combination of the variables studied, with the equation:

$\mathrm{Fi}=\mathrm{Wi} 1 \mathrm{X} 1+\mathrm{Wi} 2 \mathrm{X} 2+\mathrm{Wi} 3 \mathrm{X} 3+\ldots . .+\mathrm{WikXk}$ that is:

$\mathrm{Fi}=$ Estimated $\mathrm{i}$-th factor

$\mathrm{Wi}=$ Weight or coefficient score factor

$\mathrm{Xk}=$ The number of $\mathrm{X}$ variables in the th factor $\mathrm{k}$

\subsection{Statistics Related to Factor Analysis}

Procedure for conducting Factor Analysis:

a) Barlett's test of sphericity. It uses a trial test to test the hypothesis that variables are uncorrelated in the population. The population correlation matrix is an identity matrix; each variable is perfectly correlated with itself $(\mathrm{r}=1)$ and uncorrelated with the others $(\mathrm{r}$ $=0$ )

b) Factor loading. It is a simple correlation between variables and factors or between new variables and the variables they represent.

c) Eigenvalue. The eigenvalues represent the total variance explained by each factor. Judging from R2 $=>$, what percentage of the variance of several variants can be explained by factors. Ex: Variable 1 has a strong relationship with a factor of 1

For example, hub F1 with V1 V2 V3 is R2 $=0.81$; Then factor 1 can explain V1 V2 V3 by $81 \%$

d) Rotation. It is rotating the existing factors to facilitate interpretation.

e) Component matrix. To see which variables are included in component 1 or 2

f) Kaiser Meyer Olkin (KMO). The KMO sampling size determines whether the variables tested can be analyzed or not. If the value is reduced to 0.5 , then it cannot be analyzed. A high score $(0.5-1) \Rightarrow$ factor analysis is sufficient. If the value $<0.5 \Rightarrow$ then factor analysis is not enough.

g) Anti-image matrix. If the anti-image value is less than 0.5 , then the variable must be discarded. The process must be repeated and discarded one by one until there is no value below 0.5

Stages of Factor Analysis 1. Tabulate data in data view, 2. Formation of the correlation matrix, 3. Factor extraction, 4. Factor rotation, and 5. Naming the formed factors. 6. The whole process of data processing, using SPSS version 23 for windows. 


\section{Results and Discussion}

\subsection{Validity Test Results}

The significant test compares the calculated $r$-value with the $r$ table for the degree of freedom $(\mathrm{df})=\mathrm{n}-2$, where the sample in this study was 100 respondents, the $\mathrm{df}$ with sig 0.05 was 0.1654 Based on the data from the research and the validity test carried out, finding that of the 8 (eight) statements above, they were declared valid and worthy of being used as instruments in this study where all $\mathrm{r}$ count items were more significant than $\mathrm{r}$ table, namely 0.1654 .

\subsection{Reliability Test Results}

According to Ghozali (2016), to measure a questionnaire, a tool is needed to indicate a variable or construct to ensure reliability. A questionnaire is said to be reliable if the respondent's answer to the statement from the questionnaire is consistent or stable over time. A variable is reliable if it gives a Cronbach's Alpha Value of $>0.70$. The data processing obtained for e-marketing was 0.794 , and interest was 0.843 . It proves that the indicators contained in the questionnaire can be said to be reliable.

\subsection{Interpretation of E-Marketing Factors}

We used SPSS 2.3 software tools to analyze the data. The eight variables considered valid and reliable were then entered into factor analysis to test whether the value was more significant than the KMO and Barlett's Test values above 0.5. It is an early stage in factor analysis. The following are the stages of factor analysis used in this study.

\section{Stage 1: Tabulate Data View}

The initial stage in factor analysis is the KMO test and Bartlett's test to find out whether the factors in the study are valid or not. At this stage, the KMO and Barlette's Test numbers must be above (0.5) with the following criteria:

1. $M S A=1$, the variable can be predicted without error by the other variables.

1. MSA $>0.5$, the variable is still predictable and can be analyzed further.

2. MSA $<0.5$, the variable cannot be predicted and cannot be analyzed further or excluded from other variables

In the output, table 1 of the KMO and Bartlett's test table is in the KMO Measure of Sampling Adequacy (MSA). If the KMO MSA value is $>0.50$, then the factor analysis technique is accepted. Based on the output from the table below, it is known that the KMO MSA value is $0.748>0.50$ and Bartlett's Test of Sphericity (Sig) value is $0.000<0.05$, then the factor analysis in this study is accepted because it has met the first requirements.

Table 1. KMO and Bartlett's Test

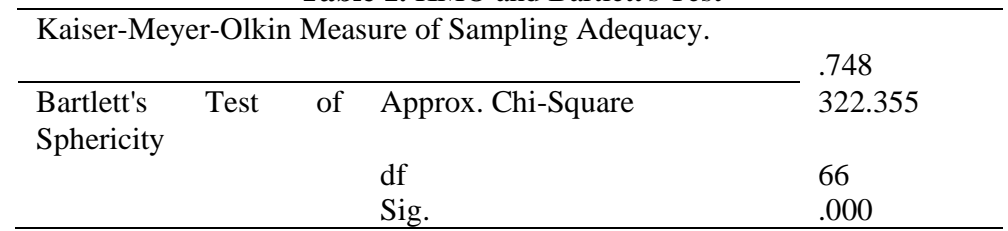




\section{Stage 2: Formation Of The Correlation Matrix}

To choose which variables can be further processed and which ones are omitted, see the Anti-image matrix table. In the Anti-image Matrice table below, specifically in the (Anti Image Correlation) section, a number marked (a) indicates the MSA amount of a variable; the results of data processing can be seen in the table below

Table 2. Table Anti-Image Matrices

\begin{tabular}{lc}
\hline \multicolumn{1}{c}{ Variable } & Anti Image Correlation \\
\hline Website & 0,493 \\
SEO & 0,700 \\
PPC & 0,562 \\
M_Afiliansi & 0,753 \\
Online_PR & 0,629 \\
Social_Network & 0,684 \\
Email_Marketing & 0,673 \\
CRM & 0,723 \\
Transaksiaonal & 0,571 \\
Referensial & 0,559 \\
Freferensial & 0,692 \\
Eksploratif & 0,680 \\
\hline
\end{tabular}

a. Measure of Sampling Adequacy (MSA)

From the results of these calculations, we found that the MSA value of each variable is $>0.50$, so from the above results, it is known that the MSA value for all the variables studied is $>0.50$. Therefore, the second requirement in this analysis is fulfilled, and all variables are accepted further.

\section{Stage 3: Extraction of factors}

This Communalities table shows the value of the variable under study whether it can explain the factor or not. The variable is considered capable of explaining the factor if the Extraction value is $>0.50$. (Santoso, 2011). Based on the results of data processing, all variables obtained were $>0.50$. Thus we concluded that all variables explain the factors. The following are the results of the commonalities analysis of the 12 variables, and further testing may proceed.

Table 3. Communalities

\begin{tabular}{lcc}
\hline \multicolumn{1}{c}{ Variable } & Initial & Extraction $^{\mathrm{a}}$ \\
\hline Website & 1,000 & 0,610 \\
SEO & 1,000 & 0,711 \\
PPC & 1,000 & 0,648 \\
M_Afiliansi & 1,000 & 0,834 \\
Online_PR & 1,000 & 0,866 \\
Social_Network & 1,000 & 0,881 \\
Email_Marketing & 1,000 & 0,637 \\
CRM & 1,000 & 0,649 \\
Transaksiaonal & 1,000 & 0,838 \\
Referensial & 1,000 & 0,865 \\
Freferensial & 1,000 & 0,675 \\
Eksploratif & 1,000 & 0,556 \\
\hline
\end{tabular}

Extraction Method: Principal Component Analysis. 


\section{Stage 4: Rotation of Factor}

The next process of factor analysis is testing Total Variance Explained. According to Santoso (2011: 85), the Total Variance Explained table describes the number of factors formed.There are 2 (two) kinds of analysis to explain a variance, namely Initial Eigen values and Extraction Sums of Squared Loading. In the Initial Eigen values variant, it shows the formed factor. If all the factors are combined, it shows the number of variables, namely $(2,685$ $+2,257+1,358+1,236+0,906+0,809+0,787+0,606+0,464+0,437+0,308+0,147=$ 12 variables). The Extraction Sums of Squared Loading section shows the number of variations or the number of factors that are formed., InI the output results below there are 4 (four) factor variations, namely $2,685+2,257+1,358+1,236$

Table 4. Total Variance Explained

\begin{tabular}{lcrrrrr}
\hline Component & \multicolumn{3}{c}{ Initial Eigenvalues } & \multicolumn{3}{c}{$\begin{array}{c}\text { Extraction Sums of Squared } \\
\text { Loadings }\end{array}$} \\
\hline & Total & $\begin{array}{c}\text { \% of } \\
\text { Variance }\end{array}$ & $\begin{array}{c}\text { Cumulative } \\
\text { \% }\end{array}$ & Total & $\begin{array}{c}\text { \% of } \\
\text { Variance }\end{array}$ & $\begin{array}{c}\text { Cumulative } \\
\text { \% }\end{array}$ \\
\hline 1 & 2.685 & 22.373 & 22.373 & 2.685 & 22.373 & 22.373 \\
2 & 2.257 & 18.806 & 41.178 & 2.257 & 18.806 & 41.178 \\
3 & 1.358 & 11.320 & 52.498 & 1.358 & 11.320 & 52.498 \\
4 & 1.236 & 10.303 & 62.802 & 1.236 & 10.303 & 62.802 \\
5 & .906 & 7.554 & 70.356 & & & \\
6 & .809 & 6.744 & 77.099 & & & \\
7 & .787 & 6.557 & 83.656 & & & \\
8 & .606 & 5.049 & 88.705 & & & \\
9 & .464 & 3.866 & 92.571 & & & \\
10 & .437 & 3.641 & 96.212 & & & \\
11 & .308 & 2.564 & 98.775 & & & \\
12 & .147 & 1.225 & 100.000 & & & \\
\hline
\end{tabular}

Extraction Method: Principal Component Analysis.

Based on the results of the Total Variance Explained output in the Initial Eigenvalues section, 4 (four) factors are formed from the 12 analyzed variables, where the requirement to become a factor, the Eigenvalues must be greater than 1. The Eigenvalues Component 1 value is 2,685 or > 1, then it becomes factor 1 and explains the 22,379\% of the variation. Eigenvalue Component 2 is $2,257>1$, then it becomes factor 2 and can explain $18.81 \%$ of the variation. The Eigenvalues Component 3 is 1.358 or $>1$, then it becomes factor 3 and can explain $11.32 \%$ of the interpretation, while the Eigenvalue component 4 is $1.236>1$, then it becomes factor 4 and can explain $10.30 \%$ of the variations. If factor 1 , factor 2 , factor 3 , and factor 4 are added together, it will explain $57.17 \%$ of the variation. Factors 5,6,7,8,9,10,11, and 12 are excluded because the eigenvalue component $<1$ means it is not a factor.

The scree plot graph below shows the formed factors, where the eigenvalue is $>1$. The chart shows that 4 Component points have an Eigenvalue $>1$, which means that only four factors are: Website, SEO, PPC, and M-affiliation factors. To explain the relationship between the number of factors formed and the eigenvalues, we use the Scree plot graph as shown in Fig 3. 


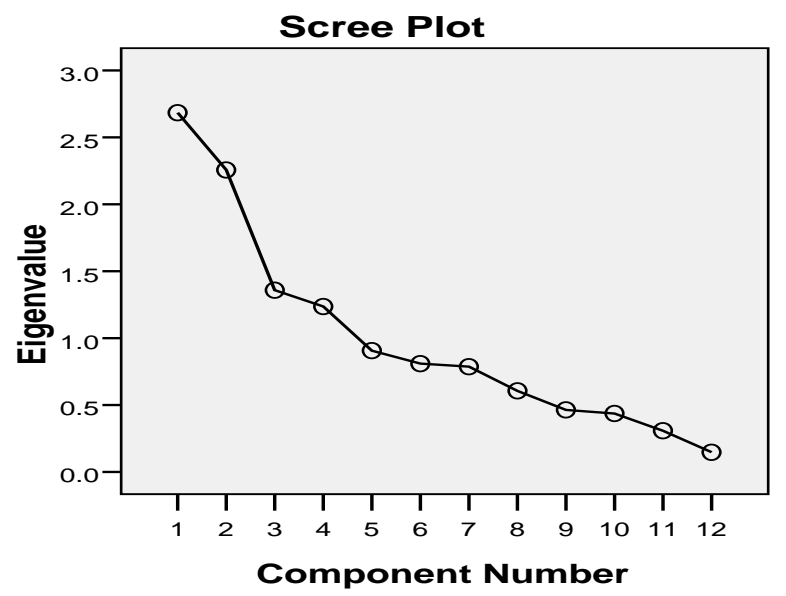

Fig.3 Screen Plot

This component matrix shows the correlation value or the relationship between each variable and the factors that will be formed. For the Website factor, the correlation value is 0.170 . The correlation with factor 2 is 0.130 , the correlation with factor 3 is 0.688 , and the correlation with factor 4 is 0.301 . For other variables, the way to interpret it is the same as in the Website variable.

Table 4. Rotated Component Matrix(a)

\begin{tabular}{|c|c|c|c|c|}
\hline \multicolumn{5}{|c|}{ Component } \\
\hline & 1 & 2 & 3 & 4 \\
\hline Website & .129 & .003 & .763 & .106 \\
\hline SEO & .423 & .146 & .086 & .532 \\
\hline PPC & .182 & .065 & .403 & .556 \\
\hline M_Afiliasi & .616 & .004 & .033 & .121 \\
\hline Online_PR & .802 & .052 & .246 & .093 \\
\hline Social_Network & .847 & .065 & .186 & .043 \\
\hline Email_Marketing & .322 & .077 & .704 & .233 \\
\hline CRM & .563 & .088 & .374 & .023 \\
\hline Transaksional & .021 & .911 & .071 & .053 \\
\hline Referensional & .041 & .929 & .014 & .016 \\
\hline Preferensional & .166 & .090 & .248 & .760 \\
\hline Eksploratif & .061 & .696 & .113 & .234 \\
\hline
\end{tabular}

Extraction Method: Principal Component Analysis.

Rotation Method: Varimax with Kaiser Normalization.

a Rotation converged in 4 iterations 
To identify which variable belongs to which factor group, look at the most significant correlation value between the variable and the formed factor (component).

The results of the rotation model factor analysis are as follows: :

1) Website variables. The correlation value of this variable with a factor of 0.129 , factor $2=0.003$, factor $3=0.763$ and factor $4=0.106$, because the correlation value of factor $3>$ from factor 1 , the website variable is included in the factor 3 group.

2) SEO variables. The correlation value of this variable with a factor of 0.423 , factor $2=$ 0.146 , factor $3=0.086$ and factor $4=0.532$, because the correlation value of factor 4 $>$ from factor 1 , the SEO variable is included in the factor 4 group.

3) PPC variables. The correlation value of this variable with a factor of 0.182 , factor $2=$ 0.065 , factor $3=0.403$ and factor $4=0.556$, because the correlation value of factor 4 $>$ from factor 1, the PPC variable belongs to the factor 4 group.

4) Variable M_Affiliate. The correlation value of this variable with a factor of 0.616 , factor $2=0.004$, factor $3=0.033$ and factor $4=0.121$, because the correlation value of factor $1>$ from factor 2, the M_Afiliation variable belongs to the factor 1 group.

5) Variable Online_PR. The correlation value of this variable with a factor of 0.802 , factor $2=0.052$, factor $3=0.246$ and factor $4=0.093$, because the correlation value of factor $1>$ from factor 2, the Online_PR variable belongs to the factor 1 group.

6) Social_Network variable. The correlation value of this variable with a factor of 0.847 , factor $2=0.065$, factor $3=0.186$ and factor $4=0.043$, because the correlation value of factor $1>$ from factor 2, the Social_Network variable is included in the factor 1 group.

7) Email_marketing variable. The correlation value of this variable with a factor of 0.322 , factor $2=0.077$, factor $3=0.704$ and factor $4=0.233$, because the correlation value of factor $3>$ from factor 1, the Email_marketing variable is included in the factor 3 group.

8) CRM variables. The correlation value of this variable with a factor of 0.563 , factor 2 $=0.088$, factor $3=0.374$ and factor $4=0.023$, because the correlation value of factor $1>$ from factor 2, the Email_marketing variable is included in the factor 1 group..

9) Transactional Variables. The correlation value of this variable with a factor of 0.911 , factor $1=0.021$, factor $3=0.071$ and factor $4=0.053$, because the correlation value of factor $2>$ from factor 1, the Transactional variable belongs to the factor 2 group.

10) Reference Variables.The correlation value of this variable with a factor of 0.929 , factor $1=0.041$, factor $3=0.014$ and factor $4=0.016$, because the correlation value of factor $2>$ from factor 1, the Reference variable belongs to the factor 2 group.

11) Preferential Variables.The correlation value of this variable with a factor of 0.760 , factor $1=0.166$, factor $2=0.090$ and factor $3=0.248$, because the correlation value of factor $4>$ from factor 3 , the Preferential variable belongs to group 4

12) Explorative Variable.. The correlation value of this variable with factor 0.696 , factor $1=0.061$, factor $3=0.113$ and factor $4=0.234$, because the correlation value of factor $2>$ from factor 1 , the exploratory variable belongs to group 2 
Table 5. Component Transformation Matrix

\begin{tabular}{ccccc}
\hline Component & 1 & 2 & 3 & 4 \\
\hline 1 & .874 & .299 & .346 & .167 \\
2 & .253 & .919 & .241 & .182 \\
3 & .360 & .182 & .877 & .261 \\
4 & .208 & .182 & .230 & .933 \\
\hline
\end{tabular}

Extraction Method: Principal Component Analysis.

Rotation Method: Varimax with Kaiser Normalization

The Component Transformation matrix shows that in component 1 the correlation value is $0.874>0.50$. For component 2 the correlation value is $0.919>0.50$. Component 3 has a correlation value of $0.877>0.50$, and component 4 has a correlation value of $0.933>0.50$ From he four factors formed we conclude that it is feasible to summarize the twelve variables analyzed.

\section{Conclusion}

1. From the analysis results, we found that the table's KMO MSA (Keiser Meyer Olkin Measure of Sampling Adequacy) value is 0.780 . The results show that the research instrument is valid since the KMO MSA (Keiser Meyer Olkin Measure of Sampling Adequacy) value does not exceed the 0.50 significance limit. In addition, Bartlett's Test of Sphericity shows a value of 322,355 with a significance of 0.000 , so we conclude that the instrument is valid. Of the 12 factors analyzed and after passing the KMO MSA analysis, there were four factors (eigenvalue > 1 to 4 ). Factor 1 can explain $22.37 \%$ of the variation, factor 2 can explain $41.18 \%$, factor 3 can explain $52.50 \%$, and factor 4 can explain $10.30 \%$. These variables are cut to 4 factors from the rotation results: Website, Search Engine Optimization (SEO), Paid search click-based advertising (PPC advertising), and affiliate marketing and strategic partnership.

2. The dominant factor in the formation of e-marketing in a marketing strategy to create interest in tourist visits to Benan Island Marine Tourism is the existence of a website. It will enable both local and foreign tourists to access information about Benan Island Marine Tourism.

\section{References}

[1] Albarq, Abbas N. 2013. "Measuring the Impacts of Online Word-of-Mouth on Tourists' Attitude and Intentions to Visit Jordan: An Empirical Study." International Business Research 7(1):p14. DOI: 10.5539/IBR.V7N1P14.

[2] Aprilia, Fitri, Srikandi Kumadji, and Andriani Kusumawati. 2015. "Pengaruh Word of Mouth terhadap Minat Berkunjung serta Dampaknya pada Keputusan Berkunjung (Survei pada Pengunjung Tempat Wisata 'Jawa Timur Park 2' Kota Batu)." Jurnal Administrasi Bisnis S1 Universitas Brawijaya 24(1):86013. doi: 10.0/CSS/ALL.CSS. 
[3] Gautam, Vinodkumar S., Akash R. Shah, Ankitkumar N. Parmar, and Vijay D. Kedariya. 2014. "Study of 6S Concept and Its Effect on Industry." International Journal of Emerging Technology and Advanced Engineering 4(10).

[4] Ghozali, Imam. 2016. Aplikasi Analisis Multivariete dengan Program IBM SPSS 23. Badan Penerbit Universitas Diponegoro.

[5] Hasan, Ali. 2013. Marketing dan Kasus-Kasus Pilihan. Yogyakarta: CAPS.

[6] Hasan, Ali, and Irma Kharisma Hatibie. 2014. "Pengaruh Elektronikal Marketing terhadap Minat Wisatawan Berkunjung ke Pulau Saronde." Jurnal Media Wisata 12(2): 162 .

[7] Iranita. 2020. "Peranan Faktor Promosi dalam Memasarkan Produk Terhadap Perilaku Pembelian Online di Masa Pandemi Covid-19 ( Studi Kota Tanjungpinang ).” Bahtera Inovasi 4(1):25-35.

[8] Kotler, Philip T., John T. Bowen, and James Makens. 2014. Marketing for Hospitality and Tourism. Pearson.

[9] Kuncoro, Mudrajad. 2009. Metode Riset Untuk Bisnis \& Ekonomi: Bagaimana Meneliti dan Menulis Tesis. Erlangga.

[10] Rangkuti, Freddy. 2013. Analisis SWOT Teknik Membedah Kasus Bisnis. Klaten: Gramedia Pustaka Utama.

[11] Reedy, Joel., Shauna. Schullo, and Kenneth. Zimmerman. 2000. Electronic Marketing : Integrating Electronic Resources into The Marketing Process. Dryden Press.

[12] Ryan, Damian. 2016. Understanding Digital Marketing: Marketing Strategies for Engaging the Digital Generation. Kogan Page Limited.

[13] Safira, Raja Ela, Winda Sholikah, and Dhidhin Noer Ady Rahmanto. 2019. "Promosi Daerah dan E - Marketing Pariwisata Halal terhadap Keputusan Berkunjung Wisatawan di Yogyakarta." ISLAMICONOMIC: Jurnal Ekonomi Islam 10(1). doi: 10.32678/IJEI.V10I1.155.

[14] Sarwono, Jonathan, and K. Prihartono. 2012. Perdagangan Online : Cara Bisnis di Internet. Jakarta: Elex Media Komputindo.

[15] Sujarweni, V. Wiratna. 2015. Metodologi Penelitian Bisnis Dan Eekonomi. Jogjakarta: Pustaka Baru. 